\title{
Current Status of E-waste and Future Perspective in Developing Countries: Benchmark Rwanda
}

\author{
Gratien Twagirayezu ${ }^{1}$, Olivier Irumva ${ }^{2, *}$, Abias Uwimana ${ }^{3}$, Jean Claude Nizeyimana ${ }^{4}$, \\ Jean Paul Nkundabose ${ }^{5}$ \\ ${ }^{1}$ School of Environmental and Municipal Engineering, Lanzhou Jiaotong University, Lanzhou, 730070, China \\ ${ }^{2}$ School of Eco-Environmental Engineering, Guizhou Minzu University 550025, China \\ ${ }^{3}$ University of Rwanda, College of Science and Technology, P.O. Box 3900, Kigali, Rwanda \\ ${ }^{4}$ School of Environment, Northeast Normal University, Changchun, 130117, China \\ ${ }^{5}$ School of Environmental Science and Engineering, Suzhou University of Science and Technology, 215009, China
}

Received December 20, 2020; Revised January 30, 2021; Accepted March 12, 2021

\section{Cite This Paper in the following Citation Styles}

(a): [1] Gratien Twagirayezu, Olivier Irumva, Abias Uwimana, Jean Claude Nizeyimana, Jean Paul Nkundabose , "Current Status of E-waste and Future Perspective in Developing Countries: Benchmark Rwanda," Energy and Environmental Engineering, Vol. 8, No.1, pp. 1 - 12, 2021. DOI: 10.13189/eee.2021.080101.

(b): Gratien Twagirayezu, Olivier Irumva, Abias Uwimana, Jean Claude Nizeyimana, Jean Paul Nkundabose (2021). Current Status of E-waste and Future Perspective in Developing Countries: Benchmark Rwanda. Energy and Environmental Engineering, 8(1), 1 - 12. DOI: 10.13189/eee.2021.080101.

Copyright $\odot 2021$ by authors, all rights reserved. Authors agree that this article remains permanently open access under the terms of the Creative Commons Attribution License 4.0 International License

\begin{abstract}
Population proliferation, economic escalation and modernization have led to a tenacious increase in the number of electrical and electronic equipment (EEE) in developing countries (DCs) particularly in Rwanda. Also, with the onset of information and communication technology (ICT), people are eager to discover new technologies, leading to robust demand for contemporary electronic devices and the use of these tools. Expired EEE are being discarded expeditiously as E-waste in bulk due to a lack of perspicuous management and treatment approach. This work is intended to describe the development of e-waste and suggests theoretical recommendations. However, it is predicated on open access articles that use e-waste as a keyword, field survey and some of the most widely studied topics namely waste management, environmental and human health effects, and the current situation of waste management in a particular region. This work reveals that the National E-waste Management Policy will restraint the life end of EEE emanating in human health protection, environment conservation, and business development concomitant to management of electrical and electronic waste (E-waste) and recycling industries, and job creation for sustainable development.
\end{abstract}

Keywords Electrical and Electronic Equipment, Information Communication and Technologies, E-waste

\section{Introduction}

To date, technology is widely embedded in all aspects of human life, and it offers users various innumerable benefits. However, fast use of emerging electronic products has proved problematic for the linear economy in handling e-waste and daily use of electronic and electronic equipment in our lives is growing by way of lifestyles and technical improvements [1]. In addition, the pursuit of new concepts and designs will indeed reduce the extent of electronic products, leading to widespread of e-waste generation systems [2]. However, once past their end of existence, were deemed hazardous for environment and human health [3]-[5]. Generally, word e-waste was described differently by the users of the concept depending on user's viewpoint [5]. According to different researchers, e-waste has different terms as a global issue [6]. At present, in this work, we have used the concept of the United Nations Environment Programme (UNEP), which describes e-waste as electronic and electrical equipment that is no longer usable to the holder or meets its end of existence, including laptops, cell phones, and others [7]. Otherwise, e-waste can be deemed as all secondary EEE including televisions, computers, mobile 
phones, refrigerators, entertainment devices, etc. However, EEE especially ICT equipment are growing increasingly around the world.

This refers to the global quantities of e-waste output, which are available for a while as emerging innovations and accessible electronics emerge [8]. Therefore, the increased numbers of electronic goods were influenced by the steadily increasing technologies and increased customer buying power. Commonly, consumption rises have environmental effects, whether from the raw materials extraction or after products use [9]. By illustration way, the estimated contribution of machines, cell phones and TVs to global e-waste was $5.5 \mathrm{Mt}$ and 9.8 Mt in 2010 and 2015, respectively[10]. Erratically to the televisions and computers, the sale and inventories of mobile telephones depend on the population, which in recent decades has seen an apparent exponential increase, as the annual amount of mobile telephones generated in 2007 has been more than one billion [11]. Currently, e-waste is one of World wide's fastest rising pollution issues given the presence of a number of harmful substances which could adulterate the environment and people's life [12]. It is crucial to regulate our use of electronics and to preserve the environment and human health, otherwise we all risk using electronics in our everyday lives [13]. However, DCs have not exempted to the impacts of the information society. These countries have implemented swiftly networks and technologies that allow limitless access to government, education, commerce and health services information [14]. These swiftly networks are built on devices that are routinely refreshed to meet customer demand, thus fueling electronic wastes at an unprecedented pace.

Some authors that have famed in ICT indicated that many DCs have been documented double-digit annual growth for first time [15]. However, if the useful life of all EEE or parts has been exhausted and the user is no longer able to use them, they are scrapped, and this signifies e-waste. The ongoing and fast progression in the EEE led to a rapidly obsolete product before its end of existence [16]. Noted that in a few years more than a billion computers will be redundant [17]. Reiterated that thousands of the previous version are scrapped when a new product is launched into the market, while it is usable and therefore creates massive quantities of e-waste. The annual global e-waste amount is expected to inflate by 2021 to an immense 53 million metric tons [18]. Tipping the digital divide allowed excluded groups to become part of the global economy [19]. Conversely, the paucity of governance and legal structures partnered with technological and socio-economic difficulties have been significant obstacles to the effective managing of e-waste [20]. In addition, it was observed that the financial problems of DCs impede the establishment of adequate recycling facilities. Unfortunately, the plurality of e-waste being processed by illegitimate and informal recyclers could pose a threat to environment and human health [21]. Moreover, These revealed that e-waste is treated in DCs by illegal and informal recyclers, which lead to contamination of environment and endanger human health as they lack the facilities for the repair, renovation, or break-up of EEE into recycling material [21], [22]. Moreover, the bulk of e-waste is disposed of by burning in landfill sites that pose environmental and human health risks [14], due to absence of e-waste segregation from other wastes.

The management of e-waste in developing countries faces substantial environmental challenges because of a lack of e-waste recycling skills and technology [23]. Research carried out in Ghana has shown that respiratory, gastro-intestinal and other infectious diseases have widespread health problems concerning informal e-waste workers [24]. And it witnessed that after the financial crisis in Zimbabwe, several institutions have favored importing cheap vicarious EEE from developed countries [25]. If e-waste is not properly monitored, handled and recycled, it has potential to cause toxic chemicals in the environment with significant consequences and harmful public health effects [26]. Elucidatively, suggesting education for informal e-waste deals on risks and adverse environmental consequences throughout the expectation that their e-waste management mindset will be improved [17], [27]. For instance, a significant impact on e-waste handling has gained in the University of Duhok's (Iraq), along with the suggestion to incorporate e-waste insights and management into curricula for environmental sustainability [21]. These indicated, in DCs, limited knowledge on a waste of EEE is a huge obstacle, users hang on to the equipment for as long as they can, partly because of the importance they attach to the equipment or because of absolute ignorance of the composition of e-waste products, but some of which are harmful to the environment and human health [4]. And e-waste could be dismantled with other waste forms. However, many organizations have no disposal strategy for e-waste [28].In addition, insufficient disposal points and an unawareness of how and why waste of EEE should be disposed of separately from other waste streams are among the factors which influence the disposal of waste by masses in DCs.

This work aimed at building awareness, reestablishing institutional and national policies for EEE management and strengthening e-waste management strategies in Rwanda. The study outcomes could be seen as an incentive for the national government to ensure national e-waste management policies and legislation for immaculate environment and development. 
Table 1. E-waste categories

\begin{tabular}{|c|c|c|}
\hline $\mathrm{N}^{\circ}$ & Categories & EEE \\
\hline 1 & Large Household Appliances & Washing machines, dryers, refrigerators; and air conditioners. \\
\hline 2 & Small Household Appliances & Vacuum cleaners, coffee machines, and iron toasters. \\
\hline 3 & $\begin{array}{l}\text { IT and telecommunication } \\
\text { equipment }\end{array}$ & $\begin{array}{l}\text { Personal computer (PC), laptops, mobile telephones, fax machines, copiers, and } \\
\text { printers. }\end{array}$ \\
\hline 4 & Consumer equipment & $\begin{array}{l}\text { Radio sets, video recorders, TVs, video cameras, audio recorders and amplifiers, } \\
\text { and musical instruments. }\end{array}$ \\
\hline 5 & Lighting equipment & Fluorescent lamps, high intensity or low sodium lamps, and metal halide lamps. \\
\hline 6 & Electrical and electronic tools & $\begin{array}{l}\text { Drills, saws machines, sewing machines, equipment for spraying, spreading, and } \\
\text { dispersing. }\end{array}$ \\
\hline 7 & Sports equipment, leisure, and Toys & $\begin{array}{l}\text { Hand-help video game consoles, car racing sets or electric trains, Coin slot } \\
\text { machines, Sports equipment with electronic and electrical components. }\end{array}$ \\
\hline 8 & Medical instruments and equipment & $\begin{array}{l}\text { Radiotherapy equipment, cardiology, dialysis, nuclear medicine, laboratory } \\
\text { equipment for in-vitro diagnosis, analyzers, and freezers. }\end{array}$ \\
\hline 9 & Surveillance and Control equipment & Smoke detector, thermostats and heating regulators. \\
\hline 10 & Automatic dispensers & Automatic dispensers for hot drinks, bottles or cans, and money. \\
\hline
\end{tabular}

\section{E-waste Status in Rwanda}

\subsection{Classification of E-waste and Sources}

E-waste refers to all EEE that holder cannot be used any longer or reaches its end of life, including cell phones, laptops, and others [7]. Otherwise, E-waste applies to any electrical and electronic equipment discarded by its users, since it is no longer recognized as being valuable unless it is reused and recycled. However, according to Rwanda National E-Waste Management Policy, e-waste encompasses all discarded and disposed electrical and electronic equipment (EEE) [29]. Furthermore, e-waste is categorized in EEE as listed in table 1 [30]. Some of the major categories of electrical and electronic equipment observed in shops for Rwanda are Television and accessories (Include Television, DVD player, Decoder, Satellite dish, Receiver cables); Computer and accessories (Such as Laptops, Desktop computers, CD-R, CD-RW \& DVD, computer speakers, Hard drives, USB sticks, CDMA sticks, Printers, Notebooks, Computer, keyboards \& mouse); Mobile devices and accessories (For instance Mobile phones, Mobile chargers (separate), Mobile phone batteries, Headsets) and Other electronic items (Like Radios, Tape recorders, Stoves, Ironing machine, Power adaptor, Power dividers, Rechargeable batteries, Men and women beauty equipment, Power cables, Different types of lamps, Refrigerators, Air conditioner, Dry cell batteries, Washing machines, Coffee grinder, Juice maker, Kettles and Vacuum cleaners).

\subsection{Tendencies and Procedures}

Recognizing the ICT's relevance to socio-economic growth as a key engine in Rwanda [31]. Project implementation like one laptop per child, fiber optic coverage whole country, increasing electricity access and other the non-aligned movement of EEE consistently emphasizes the boosting of EEE. Unfortunately, in Rwanda there is a massively increasing number of EEE in institutions, families, and companies, etc. In addition, the solid waste dealers collect wastes from various sites and dispose them at assigned waste sites without a distinct distinction of e-waste. Also, in some areas valuable and non-valuable components of e-waste are assorted with other waste types, most of them are environmentally harmful. These lead to alarming rates of e-waste generation in Rwanda. For instance, Mobile phone penetration rose from $0.0046 \%$ in 2000 to $56.8 \%$ in 2013 and Rwanda had ranked as second by the growth rate of annual mobile telephone penetration in Africa for 2010 [32], [33]. Moreover, from November 2014 to January 2015 in Rwanda has surveyed to establish the condition of E-Waste, it contemplated that the import of ICT equipment has risen by five times between 2010 and 2014. Generally, Rwanda's annual E-Waste production capacity was 9417 tons, of which 7,677 tons (81.52\%) are imparted by persons, 1,143 tons $(12.14 \%)$ by the public organization, and 597 tons $(6.34 \%)$ of a private organization, this work revealed that Rwanda has the potential to produce e-Waste annually [29], [34].

Additionally, in terms of engendering and handling e-waste is conspicuously trending at a higher level and the annual increase rate in EEE imports into Rwanda was estimated to be approximately 5.95\%. Distinctly, in 2014 and $2020,8790255.66 \mathrm{~kg}, 12432416.6 \mathrm{~kg}$ of e-waste was generated from $33449623.04 \mathrm{~kg}$ and $47309164.3 \mathrm{~kg}$ of EEE, which estimate the generation of $16596528.74 \mathrm{~kg}$, $22155368.07 \mathrm{Kg}, 70359994.68 \mathrm{~kg}$ for e-waste, which will be produced by $63154890.07 \mathrm{~kg}, 84307981.33 \mathrm{~kg}$, and $267741393.3 \mathrm{~kg}$ of EEE in 2025,2030 and 2050, respectively, as evinced in Fig 1 [35]. Currently, there are no requirements for e-waste management and the residents are entailed to pay for the compilation and disposal services only like other wastes. However, E-waste cannot be handled as general waste due to its unique opus, which embodies infrangible materials that could threaten the environment. These necessitate special disposal techniques, expertise, and specific facilities. 


\section{Trends of E-waste in Rwanda}

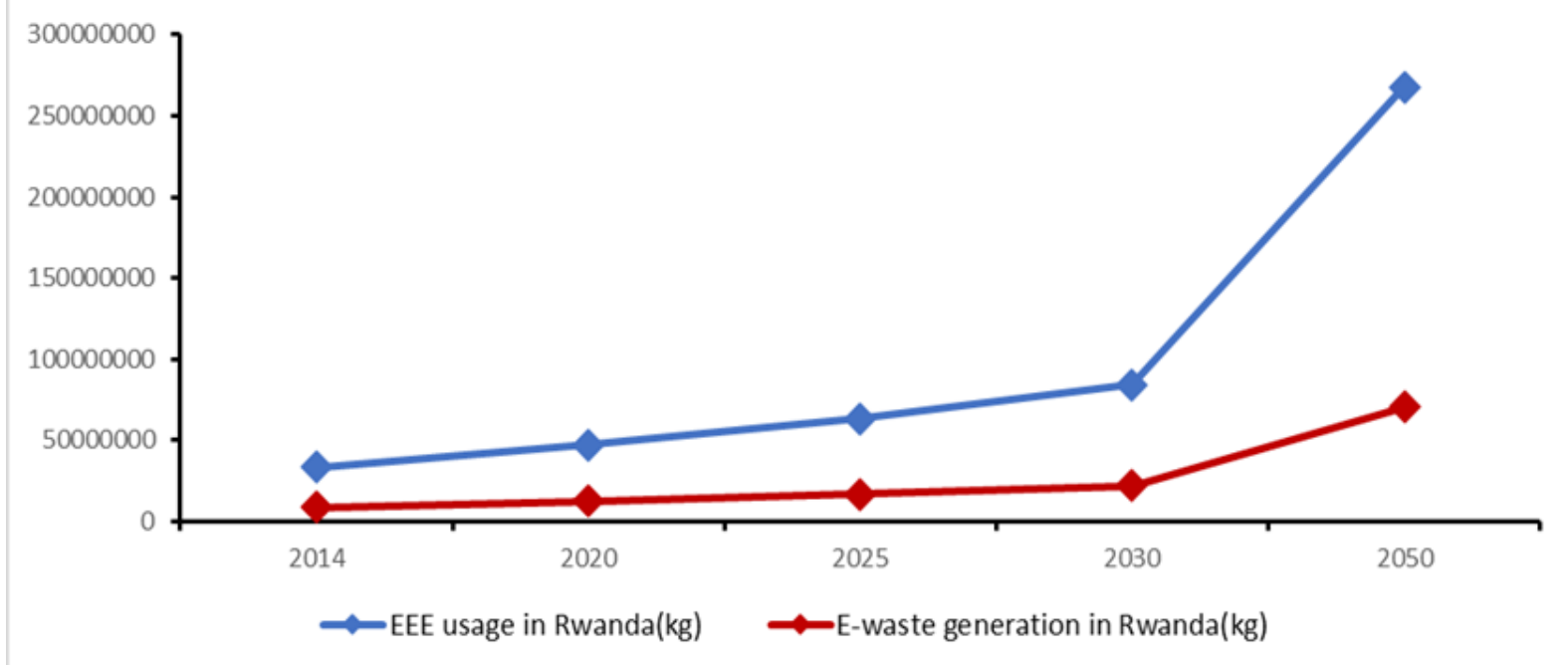

Figure 1. E-waste trends in Rwanda

\subsection{Structures and Procedures for E-waste Management}

As efforts to boost ICT are gaining momentum, the handling of e-waste is becoming significant to sustainability policies [31]. Rwanda is a country that is increasingly boosting technology, electronic devices such as laptops, TVs, computers and smartphones, etc. These have driven to substantial increases in e-waste combined with strong demand from customers for the new smartphones. These indicated that there is a need of e-waste management in Rwanda. Through the Ministry of Trade, the government of Rwanda has in partnership with the Rwanda Green Fund, worked to solve this issue even if it's not all due to population's awareness. The denouement is the installation of recycling and dismantling plant in Rwanda, which is formalized an e-waste processing and recycling facility of world-class capable of handling more than 7,000 tons of EEE waste per year. This facility is Africa's second-largest and reflects the clear commitment of Rwanda to green growth and sustainability [36].

Furthermore, all these following institutions should implement their functions in the e-waste recycling system with the Ministry of Trade, Industry and East African Community Affairs (MINEACOM) in charge of external trade, etc.; Ministry of Infrastructure(MINIMFRA)in charge of national policies, institutional and legal frameworks, strategies and master plans concerning to transport, energy, etc.; Ministry of Youth and ICT( MYICT) in charge of ICT policies and programs; Rwanda Standards Board( RSB) in charge of product, collection, dismantling and treatment standards; National Fund for Environment and Climate Change ( FONERWA) in charge of Fund management; Rwanda Environment Management Authority ( REMA) in charge of
Environmental compliance and performance coupled with transboundary shipments; Energy Private Developers( EPD) in charge of regathering all private companies wielding in the energy sector and Extended Producer Responsibility (EPR) in charge of the product life cycle as evinced in Fig 2 [37]. FONERWA funded e-waste recycling facility is a part of its e-waste involving inventorisation, creation of policies, and private investment. And there are management systems and processes to raise and disburse funds that can be easily tailored to the specifications of a particular EPR fund. At present, without the need for compensation from EPR assets, the private partner running the facility plans to be profitable. However, this is supposed to be free to access waste, highly dependent on high-value IT waste and reasonably high metal prices. If access to waste costs and the costs of proper disposal of hazardous fractions rises, therefore economic viability needs to be rebalanced by additional funding, which normally comes from EPR funds. However, as a partner in the recycling facility, FONERWA can be found in a conflict of interest if such fund payments are nuts. The role of the EPR fund manager can also be performed by industry-led private or not-for-profit organizations similar to the European producers' accountability organizations. EPD, along with other industrial organizations under the Private Sector Federation, which also includes the Rwandan ICT Chamber, representing resellers of IT equipment and telecoms firms, may be able to play this role in the off-grid solar industry. Other governments such as RURA, REMA, and RSB are well-positioned to provide licensing, supervision, and aid on various issues, such as cross-border deliveries and monitoring, set standards, etc. Their ability to and interest in accepting such a mandate should however be assessed. 


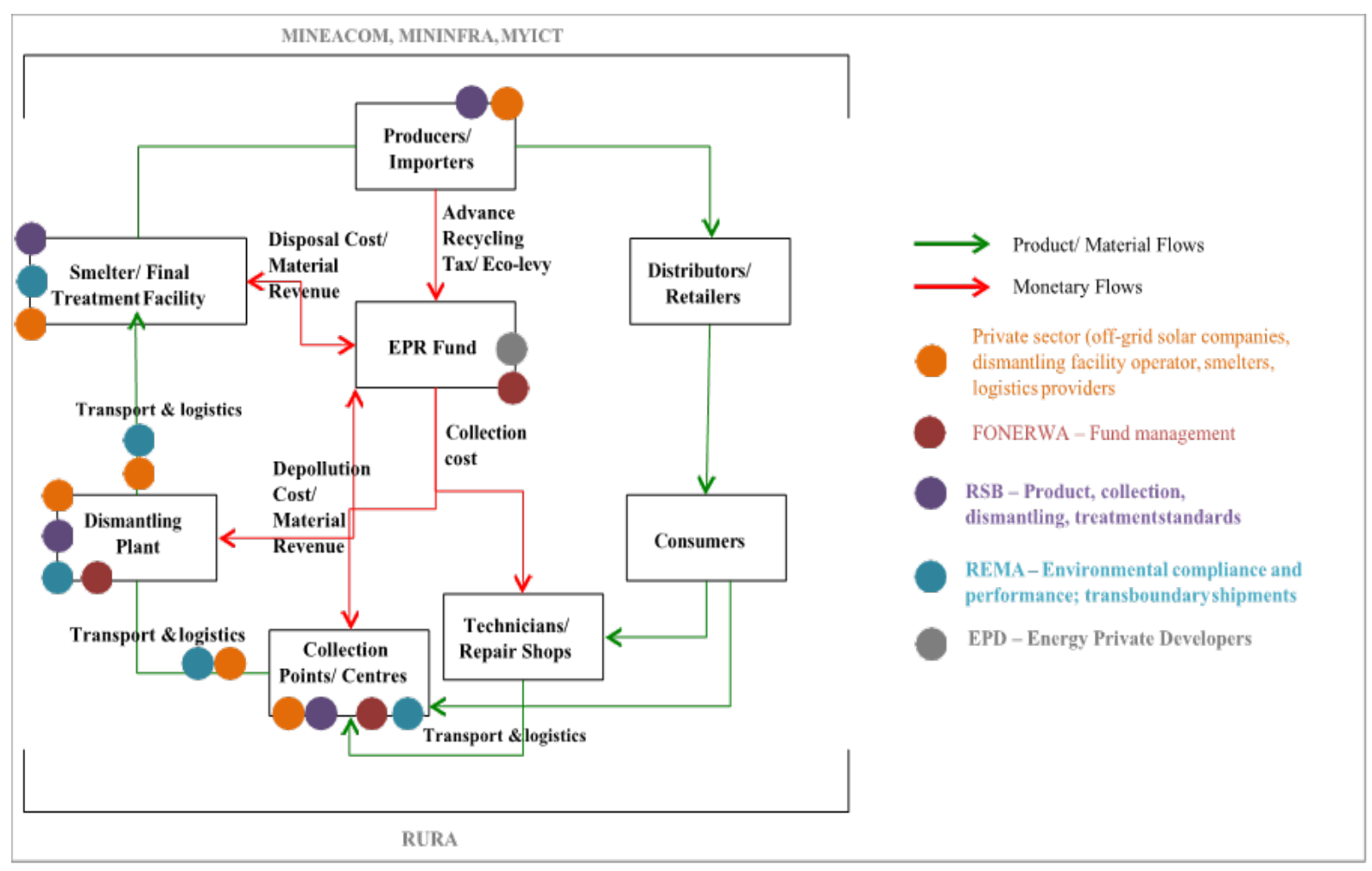

Figure 2. Government-Private Recycling Scheme Hybrid

\subsection{Current Policy and Legal Framework}

Generally, Rwanda Government is committed to environmental protection agencies due to e-waste increment. However, there is no standardized e-waste management process in different sectors. For this, Rwanda has drawn up a national e-waste management strategy acknowledging environmental degradation and climate change as one of the key impediments to the fulfillment of medium and long-term growth aspirations [29], [31]. Distinctly, Rwandan officials considered developing policy international conventions such as the Basel Convention on Regulation of and Disposal of Transboundary Movements for Hazardous Wastes, the Stockholm Convention on Persistent Organic Pollutants, the World Charter on Biodiversity, the Vienna Convention on Ozone Security, and the Millennium Development Goals [38]. Among other statements and declarations of principle, such as the Rio Declaration on Environment and Development in 1992, are support for the provisions of Agenda 21. Rwanda is also a partner of the Basel Convention for Control and Disposal of Transboundary Movements of Dangerous Wastes, which has been established to ensure, minimizing the generation of hazardous waste and other wastes; adequate disposal facilities for sound environmental waste management; and minimizing the hazard to health by waste managers. However, Rwanda has identified waste as a danger in its environmental protection policies in general through environmental policy and legal structure but failed to foresee the particular issues posed by e-waste. This does not address e-waste management enough in the current policies, legal, and regulatory system. It is rather treated as a sub-set under the regulations on hazardous waste control and management [29]. As the current waste law in Rwanda is broad and does not explicitly include an extensive e-waste management approach, the existing legal framework must be revised with a comprehensive strategy to include e-waste regulation to protect the environment and health for Rwandans. Table 2 offers a summary of Rwanda's national laws, policies, and regulations on e-waste management to uphold national and international conventions and agreements and to resolve the challenges of a changing technological climate. 
Table 2. Rwanda e-waste laws, environmental policy, and legal framework

\begin{tabular}{|c|c|c|}
\hline Laws or regulations & Environment policy and legal framework & Source \\
\hline $\begin{array}{l}\text { The Law No } 39 / 2001 \text { of } 13 \text { th September } \\
2001\end{array}$ & $\begin{array}{l}\text { Initiating Rwanda Utilities Regulatory Agency (RURA) by offering } \\
\text { obligation for the disposal of waste materials from residential or } \\
\text { commercial premises, among many others. }\end{array}$ & [39] \\
\hline $\begin{array}{l}\text { The Environment Organic Law } N^{\circ} 04 / 2005 \\
\text { of } 08 / 04 / 2005\end{array}$ & $\begin{array}{l}\text { Ascertaining the ways of protecting, conserving, and facilitating the } \\
\text { environment in Rwanda, indicates that waste collection, } \\
\text { transportation, and disposal are to be done concerning the } \\
\text { environment, but does not address the problem of e-waste } \\
\text { management sufficiently and explicitly. }\end{array}$ & [40] \\
\hline The Law $N^{\circ} 16 / 2006$ of $03 / 04 / 2006$ & $\begin{array}{l}\text { inducting Rwandan Environment Management Agency (REMA) } \\
\text { organization, operations, and obligations, some of the obligations are: } \\
\text { to execute the environmental policy, to review and authorize EIAs for } \\
\text { development projects, and to prepare environmental hazard } \\
\text { prevention action plans. }\end{array}$ & [41] \\
\hline The Law No $43 / 2010$ of $07 / 12 / 2010$ & $\begin{array}{l}\text { authorizing Energy, Water and Sanitation Authority (EWSA) In } \\
\text { delineating its roles, organizations, and functions and sets out and } \\
\text { defines its responsibilities, including to create modes of transportation } \\
\text { and waste management. }\end{array}$ & [42] \\
\hline The law No: 1 of $25 / 10 / 2011$ & $\begin{array}{l}\text { established by Rwanda Standard Board (RSB) in collaboration with } \\
\text { the ministry in charge of ICT related to the importation of used } \\
\text { electronics/ICT equipment, aimed to restrict and regulate importation } \\
\text { of used computers and electronic parts, to minimize EEE's potential } \\
\text { adverse effect on human health and the environment. }\end{array}$ & [29] \\
\hline The law $N^{\circ} 09 / 2013$ of $01 / 03 / 2013$ & $\begin{array}{l}\text { Initiating Rwanda Utilities Regulatory Authority (RURA) and } \\
\text { determining its mission, powers, organization and functioning and law } \\
\mathrm{N}^{\circ} 16 / 2013 \text { in ascertaining the functioning, organization, and } \\
\text { responsibilities of Rwanda Environmental and Management (REMA) } \\
\text { allots with the management of waste and regulations, leaving out } \\
\text { discrepancies in e-waste in general context. }\end{array}$ & [43] \\
\hline The law $\mathrm{N}^{\mathrm{o}} 24 / 2016$ of $18 / 06 / 2016$ & $\begin{array}{l}\text { Governing ICT especially in article } 130\left(6^{0} \mathrm{~K}\right) \text {. The ICT Act, } \\
\text { No24/2016 of } 18 \text { June } 2016 \text { is entitled to decide the requirements to be } \\
\text { met and to provide information for anyone who wants to create and } \\
\text { run a network, or to provide electronic communications services for } \\
\text { the purpose of obtaining a license. }\end{array}$ & [44] \\
\hline $\begin{array}{l}\text { NÛ 011/R/STD-ICT/RURA/020 OF } \\
\text { 29/05/2020 }\end{array}$ & $\begin{array}{l}\text { This Regulation is intended to establish a regulatory structure for } \\
\text { import, supply, and form approval of Rwandan electronic } \\
\text { communications equipment to assure that electronic communication } \\
\text { equipment may be linked to the Public Telecommunications Networks } \\
\text { without causing any harm to the Public Telecommunications } \\
\text { Networks. }\end{array}$ & [45] \\
\hline
\end{tabular}

\subsection{E-waste Policies and Institutional Framework}

The application of the policies requires an effective institutional structure as well as a consistent mechanism for collaboration between all stakeholders, as e-waste is created by activities at both public and private sectors. A steering committee will be set up quickly to monitor and promote the implementation of the policies in order to ensure efficient and sustainable management of waste. The Committee will also organize all procedures for the improvement of proper e-waste management in Rwanda. The ICT Minister shall co-chair the Steering Committee by the Minister responsible for the environment. Consequently, in partnership with key stakeholder organizations with the following roles and responsibilities defined in table 3 [29], e-waste policies shall be enforced. 
Table 3. Propounded institutions with duties and responsibilities for e-waste superintendence

\section{Institutions}

Ministry in charge of Information and

Communications Technology (ICT)

Ministry in charge of Trade and Industry

Ministry in charge of Health

Ministry in charge of Education

Ministry in charge of State Assets

Authority in charge of the Protection of the Environment

ICT Regulatory Authority

Authority in charge of Standards

Authority in charge of Imports Inspection

Authority in charge of Customs and Revenues

Private sector

EEE Users

\section{duties and responsibilities}

1. Lead e-waste policy and strategic plan development for e-waste management.

2. Monitor the implementation of the E-waste strategic plan in coordination with the Ministry in charge of Trade and Industry

1. Management of e-waste facilities, processes, and sustainable consulting framework.

2. E-waste management funding system, such as advanced recycling fee, e-waste operating and management procedures.

1. The Health Ministry will establish health and safety standards related to e-waste management policies.

1. The Ministry responsible for education establish and incorporate e-waste management processes within curricula.

2. The Ministry will concentrate on developing the requisite skills for the proper management of waste, including recycling, at local and national level.

1. State assets ministry will develop spotless procedures for e-waste Management facilities before the decommissioning of EEE.

1. vanguard e-waste mainstreaming in current environmental policy, strategy, regulatory and legal tools.

2 . be involved in the informative contemplation on e-waste as baseline surveys, etc.

3. Control implementation of e-waste-management environmental programs.

These policies are enforced by the ICT Regulatory Authority:

1. Providing regulations guiding e-waste management in Rwanda.

2. Providing e-waste management and disposal technical guidance.

3. impose the licensing scheme for the organization's deals with EEE collection, transport, removal, restoration and recycling.

1. inform member states of the World trade organization on instigated EEE standards, regulations, and policies that harm the imported quality into the country.

2. Developing standards for e-waste management.

3. develop an E-Waste Management Standards Auditing and Monitoring mechanism.

1. The import inspection authority shall ensure that all electrical and electronic equipment imported are complied with by specified specifications at the time of entry.

1. Both EEE produced in Rwanda and imports will remain registered with the customs and revenue authority.

1. the private sector shall introduce E-waste management policies and strategic plans Via planning and establishment of e-waste collection, transport, disposal, and recycling facilities.

2. In addition, the private sector shall also be in charge of developing, maintaining, and funding the entire E-waste chain.

1. Distinct e-waste from others to enable the collection, recycling, and treatment.

2. Emplace generated e-waste to licensed centers and drop-off points.

3. be moderated with the suggested methods or procedures for disposal, particularly the expiry or end of the product usage period. 


\section{Environmental and Health Ramification}

Inadvertently the harmful effects, E-waste has been discarded by unconscious social citizens in agricultural land, the open sources of water bodies and open sites. Numerous studies have described that high levels of toxic metals such as lead $(\mathrm{pb})$, cooper $(\mathrm{Cu})$, mercury $(\mathrm{Hg})$ etc., and organic pollutants such as polybrominated dibenzo-p-dioxins/ dibenzofurans (PCBB/Fs), polycyclic aromatic hydrocarbons (PAHs), polychlorinated biphenyls (PCBs) spot in soil, air, water and sediments which are close the individual activities[46], [47]. Also, for the open disposal of hazardous e-waste in water sources and landfills adulterate the groundwater [48]. These toxic pollutants may affect workers and local residents via dermal exposure, direct inhalation, and oral intake of water, and food. In addition, e-waste is associated with a wide variety of materials, some of which contain harmful substances that can pollute the environment and endanger human health unless properly handled. Methods for e-waste disposal include incineration and landfill that pose major pollution risks[49]. These toxic materials can be transported by landfill leachate into groundwater while toxic gases may be released into the atmosphere by burning in the incineration process. E-waste recycling can disperse dangerous substances into the atmosphere, particularly if the recovery industry at best is moderately profitable and sometimes cannot take the proper measures in order to protect the environment and health of employees.

Both main components and ecological health face a major challenge and pose a danger to the ecosystem by e-waste disposal [50]. Due to lack of awareness, In Rwanda, e-waste are not segregated from other waste and are stored in improper containers, like pre-packaging rice, sugar, and flavor, these packages can be damaged when they contain wet or liquid substances. Some households often use old and damaged materials that can harm them. During waste collection day, containers are placed around the street, unloaded waste is taken and returned to their owner for reusing, which means that there are waste issues. Moreover, waste trucks are packed or unpacked manually by laborers without proper accoutered such special work, the waste worker and even the ecosystem are not safe and stable in such activities. Good health mechanisms should be set up by local authorities and waste collection firms to lad and unlade these waste trucks to ensure safety for employees. Again, educational drives should be considered about the health effects of these heavy metals in these e-wastes[51].

Generally, there are even more than 1000 hazardous substances [49], linked with e-waste. The most widely mentioned substances are Polyvinyl chloride (PVC), toxic metals, persistent organic pollutants (POPs) [52]. As shown in table 4[53], e-waste contains toxic heavy metals and organic contaminants. To prevent harming or jeopardizing human health and the environment, Rwanda government should highlight proper segregation of e-waste from the household and enforce policies and regulations regulating the transport and disposal of e-waste collection. Also, the effects of heavy metals such as Arsenic (As), Mercury (Hg), Nickel (Ni), Selenium (Se), etc. should be studied in combating these chronic diseases and gradually observed disease, including toxic environments and environmental changes. 
Table 4. Popular e-waste-related toxic substances and their health effects

\begin{tabular}{|c|c|c|}
\hline Substance & Location in e-waste & Health Impacts \\
\hline Antimony (Sb) & $\begin{array}{l}\text { Plastic computer housings, a melting agent in } \\
\text { CRT glass and a solder alloy in cabling }\end{array}$ & $\begin{array}{l}\text { Sb has been categorized as a carcinogen. The inhalation of } \\
\text { high levels of antimony over a long time can cause stomach } \\
\text { pain, vomiting, diarrhea, and stomach ulcers. }\end{array}$ \\
\hline Arsenic (As) & $\begin{array}{l}\text { gallium arsenide was been used In Light } \\
\text { Emitting Diodes. }\end{array}$ & $\begin{array}{l}\text { It has systemic effects, contributing to skin disease, lung } \\
\text { cancer and impaired signaling of the nerve. }\end{array}$ \\
\hline Barium (Ba) & $\begin{array}{l}\text { CRT gutters in vacuum tubes, Sparkplugs, and } \\
\text { fluorescent lamps }\end{array}$ & $\begin{array}{l}\text { Via Short-term exposure, it causes brain swelling, } \\
\text { weakness of muscles, heart, liver and spleen damage. }\end{array}$ \\
\hline Beryllium (Be) & $\begin{array}{l}\text { finger clips, motherboards, Power supply } \\
\text { boxes, and relays. }\end{array}$ & $\begin{array}{l}\text { Be is classified as a carcinogen.it can cause lung cancer, } \\
\text { skin disease and berylliosis. }\end{array}$ \\
\hline $\begin{array}{l}\text { Brominated flame } \\
\text { retardants (BFRs) }\end{array}$ & $\begin{array}{l}\text { They have been used to lower flammability in } \\
\text { plastic housings, cable insulation, printed } \\
\text { circuit boards and keyboards. Among them } \\
\text { there are Polybrominated diphenyl ethers } \\
\text { (PBDEs), tetrabromobisphenol } \\
\text { (TBBPA) and polybrominated biphenyls } \\
\text { (PBBs) }\end{array}$ & $\begin{array}{l}\text { Printed circuit boards and plastic casings emit toxic vapors } \\
\text { believed to cause hormonal disturbances during } \\
\text { combustion. }\end{array}$ \\
\hline Cadmium (Cd) & $\begin{array}{l}\text { infrared detectors, printer inks, Rechargeable } \\
\text { NiCd batteries, semiconductor chips, and } \\
\text { toners. }\end{array}$ & $\begin{array}{l}\text { Cadmium compounds present a risk of irreversible human } \\
\text { health effects, especially the kidneys. }\end{array}$ \\
\hline $\begin{array}{l}\text { Chlorofluorocarbons } \\
\text { (CFCs) }\end{array}$ & insulation foam, and cooling units. & $\begin{array}{l}\text { These pollutants damage the ozone layer, and the } \\
\text { occurrence of skin cancer could be increased. }\end{array}$ \\
\hline $\begin{array}{c}\text { Hexavalent } \\
\text { chromium/chromium } \\
\text { VI (Cr VI) } \\
\end{array}$ & $\begin{array}{l}\text { Hard dics, plastic computer housing, colorant } \\
\text { in pigments and cabling }\end{array}$ & $\begin{array}{l}\text { Is highly toxic to the environment, causing damage to DNA } \\
\text { and permanent damage to the eye. }\end{array}$ \\
\hline Lead $(\mathrm{Pb})$ & $\begin{array}{l}\text { cathode-ray tubes, Solder, fluorescent tubes, } \\
\text { cabling, lead-acid batteries, and printed circuit } \\
\text { boards. }\end{array}$ & $\begin{array}{l}\text { Can harm the brain, nervous system, kidney, reproductive } \\
\text { system and } \\
\text { Blood disorders are induced. Low levels of lead in fetuses } \\
\text { and young children can damage the brain and nervous } \\
\text { system. The build-up of lead in the atmosphere has both } \\
\text { chronic and acute health effects }\end{array}$ \\
\hline Mercury (Hg) & $\begin{array}{l}\text { Thermostats, Flat panel displays, switches, } \\
\text { backlight bulbs or lamps and batteries. }\end{array}$ & $\begin{array}{l}\text { The brain, kidneys and fetuses may be damaged by } \\
\text { Mercury. }\end{array}$ \\
\hline Nickel (Ni) & $\begin{array}{l}\text { Printed circuit boards, computer housing, } \\
\text { Batteries, and cathode ray Tube. }\end{array}$ & $\begin{array}{l}\text { Can cause allergic reactions, bronchitis, and decreased } \\
\text { pulmonary function; and lung cancer. }\end{array}$ \\
\hline $\begin{array}{c}\text { Polychlorinated } \\
\text { biphenyls (PCBs) }\end{array}$ & $\begin{array}{l}\text { heat transfer fluids, condensers and } \\
\text { transformers. }\end{array}$ & $\begin{array}{l}\text { PCBs can cause animal cancer and can cause human liver } \\
\text { damage. }\end{array}$ \\
\hline $\begin{array}{l}\text { Polyvinyl chloride } \\
\text { (PVC) }\end{array}$ & $\begin{array}{l}\text { Keyboards, plastic computer housing, } \\
\text { monitors, cabling and cabling. }\end{array}$ & $\begin{array}{l}\text { PVC has the potential for harmful air pollution and } \\
\text { dangerous substances. Incomplete combustion of PVC } \\
\text { produces vast quantities of hydrogen chloride gas, which in } \\
\text { combination with humidity forms hydrochloric acid. } \\
\text { Hydrochloric acid can cause breathing difficulties. }\end{array}$ \\
\hline Selenium (Se) & Older computers for photocopying & Large levels contribute to selenosis. \\
\hline
\end{tabular}

\section{Awareness for E-waste Management}

The evaluation of the status and developments in e-waste management in Rwanda has shown a limited understanding of the risks associated with the unsatisfactory management and disposal of e-waste in some public and private sectors and the Rwandan population in general. Commonly, enhancing e-waste management's national awareness and ability could boost investment and job creation in processing and recycling [29]. It was publicized that those items discarded have a detrimental effect on the environment. In addition to affecting the environment, it can also affect people's health; hence it is necessary to manage the waste efficiently. And it is good to build a campaign to sensitize electronic waste. Additionally, it's even better to make people notice it. The more e-waste users are conscious, the proper management emerges due to demand for electronic goods, product lifecycles easily lessen. Although users cannot track the use of scarcely used electronics by other people. Therefore, it is crucial to raise awareness about e-waste and enable people to know the correct disposal process.

\section{Recommendations}

\subsection{Effective E-waste Management Regulatory Framework}

An efficacious regulatory framework is required for shipping monitoring, proper labeling, and e-waste recycling. Yet, Rwanda has already adopted severe EEE management legislation. In addition, Rwanda has official 
e-waste collection sites and dismantling plant. However, there are still e-waste management issues particular in some institutions and local areas. Due to population escalation, beliefs and awareness of citizens and actual e-waste situation that make regulations hard to enact are the most important issues. Moreover, propelled by development and other crucial government issues root local governments not to be attentive to informal e-waste processing and disposal. In these situations, the Rwanda government should ensure that the EEE policies is consistently implemented.

\subsection{Rwanda's Formal Sector Strong Development}

Although Rwanda has some recycling pilots' programs, it's crucial to develop strong formal recycling processes, which are environmentally conscious. Generally, some informal recycling cannot be banned in a short period as the prevalent means for a waste of EEE. Therefore, the key issue is how the informal sector can be transferred or incorporated into the formal sector. In the current e-waste disposal and recycling sectors, pricing plays a key role. Consequently, to encourage formal recycling, Rwanda government should draw up fair recovery costs and recovery schemes. In addition, all collaborations involving customers, retailers, public authorities, e-waste producers, and academics, among others should discuss e-waste issues.

\subsection{Extended Producer Responsibility (EPR)}

For effective e-waste management, extended producer responsibility (EPR) is a crucial strategy that could be reinforced by Rwanda government. Under this situation, Rwanda should take concrete steps to strengthen the existing EPR. Although Rwanda's Waste of EEE regulations don't focus on the end-use treatment of consumer goods. Its primary aim is to recover in quantity and extent to minimize the effect of waste materials on the environment. Also, there is no detailed explanation for recycling fees, waste of EEE and virgin products regulations, and time to bring them into effect. Therefore, there is a need of a strong approach for EPR.

\section{Conclusions and Future Work}

As tremendous amounts of e-waste are being produced each year, Rwanda countenances issues in both wastes of EEE production and awareness. However, Rwanda's formal recycling sectors should play a much more prominent role in evading various environmental and health concerns. Via analysis and comparison with developed countries of the current legal system. This work highlights the importance of the regulatory framework and the application of EPR. Furthermore, Rwanda government and companies should have more effects to focus on the span of product life for a bright future. Additionally, the future requires the development of a database for all EEE from various suppliers, which will ensure that manufacturers and importers are accountable for the collection and recycling of old items. Secondly, innovative techniques may be utilized at border points and airports with the goal of monitoring smuggled devices. Conspicuously, a significant impact on e-waste handling should be gained, along with the suggestion to incorporate e-waste insights and management into Rwanda education curricula for environmental sustainability.

\section{REFERENCES}

[1] M. Sharma, S. Joshi, and A. Kumar, "Assessing enablers of e-waste management in circular economy using DEMATEL method: An Indian perspective," Environ. Sci. Pollut. Res., pp. 1-14, 2020.

[2] L. Wei and Y. Liu, "Present status of e-waste disposal and recycling in China," Procedia Environ. Sci., vol. 16, pp. 506-514, 2012.

[3] ITU, "The growing challenge of e-waste," https://www.itu.i nt/en/mediacentre/backgrounders/Pages/e-waste.aspx, 2019 . .

[4] WHO, "WHO | Electronic waste," http://www.who.int/ceh/r isks/ewaste/en/, 2020.

[5] V. Onyara, "E-Waste as Perceived by Different World Economies: Critical Review of Literature," Int. J. Curr. Asp., vol. 4, no. 1, pp. 33-42, 2020.

[6] S. B. Wath, P. S. Dutt, and T. Chakrabarti, "E-waste scenario in India, its management and implications," Environ. Monit. Assess., vol. 172, no. 1-4, pp. 249-262, 2011.

[7] Unep, "Call for Global Action on E-waste." United Nations Environment Programme, 2006.

[8] F. O. Ongondo and I. D. Williams, "Mobile phone collection, reuse and recycling in the UK," Waste Manag., vol. 31, no. 6, pp. 1307-1315, 2011.

[9] L. Halim and Y. Suharyanti, "E-Waste: Current Research and Future Perspective on Developing Countries," 2020.

[10] G. P. Boretos, "The future of the mobile phone business," Technol. Forecast. Soc. Change, vol. 74, no. 3, pp. 331-340, 2007.

[11] A. Reller, T. Bublies, T. Staudinger, I. Oswald, S. Meißner, and M. Allen, "The mobile phone: Powerful communicator and potential metal dissipator," GAIA-Ecological Perspect. Sci. Soc., vol. 18, no. 2, pp. 127-135, 2009.

[12] A. Shamim, A. K. Mursheda, and I. Rafiq, "E-waste trading impact on public health and ecosystem services in developing countries," J Waste Resour., vol. 5, no. 188, p. 2, 2015.

[13] K. V. Nartey, "Environmental and health impacts of informal e-waste recycling in agbogbloshie, accra, ghana: 
recommendations for sustainable management," Bonn, Ger. Rheinische Friedrich-Wilhelms-Universität Bonn, 2016.

[14] C. P. Baldé, V. Forti, V. Gray, R. Kuehr, and P. Stegmann, The global e-waste monitor 2017: Quantities, flows and resources. United Nations University, International Telecommunication Union, and ..., 2017.

[15] R. Heeks, L. Subramanian, and C. Jones, "Understanding e-waste management in developing countries: Strategies, determinants, and policy implications in the Indian ICT sector," Inf. Technol. Dev., vol. 21, no. 4, pp. 653-667, 2015.

[16] D. Mmereki, B. Li, A. Baldwin, and L. Hong, "The generation, composition, collection, treatment and disposal system, and impact of E-waste," E-Waste Transition-From Pollut. to Resour., pp. 65-93, 2016.

[17] B. Debnath, R. Roychoudhuri, and S. K. Ghosh, "E-waste management--a potential route to green computing," Procedia Environ. Sci., vol. 35, pp. 669-675, 2016.

[18] S. N. M. Menikpura, A. Santo, and Y. Hotta, "Assessing the climate co-benefits from Waste Electrical and Electronic Equipment (WEEE) recycling in Japan," J. Clean. Prod., vol. 74, pp. 183-190, 2014

[19] J. Moon, M. D. Hossain, H. G. Kang, and J. Shin, “An analysis of agricultural informatization in Korea: the government's role in bridging the digital gap," Inf. Dev., vol. 28, no. 2, pp. 102-116, 2012.

[20] G. D. Ashwani, "Evaluating critical barriers to implementation of WEEE management using DEMATEL approach," Resour. Conserv. Recycl., vol. 131, pp. 101-121, 2018, doi: https://doi.org/10.1016/j.resconrec.2017.12.024.

[21] N. Arif and R. Afroz, "Electrical and Electronic Waste Management--A Case Study in University of Duhok, Iraq," Int. J. Econ. Manag. Eng., vol. 3, no. 2, pp. 68-73, 2013.

[22] A. Kumar, M. Holuszko, and D. C. R. Espinosa, "E-waste: an overview on generation, collection, legislation and recycling practices," Resour. Conserv. Recycl., vol. 122, pp. 32-42, 2017.

[23] F. F. Rochman, W. S. Ashton, and M. G. M. Wiharjo, "E-waste, money and power: Mapping electronic waste flows in Yogyakarta, Indonesia," Environ. Dev., vol. 24, pp. $1-8,2017$.

[24] J. Amankwah-Amoah, "Global business and emerging economies: Towards a new perspective on the effects of e-waste," Technol. Forecast. Soc. Change, vol. 105, pp. 20 26, 2016.

[25] J. W. Chitotombe, "Globalization of Information Communication Technology (ICT) and consumerism in developing countries: Confronting the challenges of e-waste disposal in Harare urban, Zimbabwe," Int. J. Environ. Sci., vol. 3, no. 6, pp. 2172-2185, 2013.

[26] A. Borthakur and M. Govind, "Computer and mobile phone waste in urban India: an analysis from the perspectives of public perception, consumption and disposal behaviour," $J$. Environ. Plan. Manag., vol. 62, no. 4, pp. 717-740, 2019.

[27] W. Nwagwu and M. Okuneye, "Awareness and attitudes of small-scale information technology business operators in Lagos, Nigeria toward E-waste hazards," J. Glob. Inf Technol. Manag., vol. 19, no. 4, pp. 267-282, 2016.
[28] D. Koloseni and F. Shimba, "E-Waste Disposal Challenges and Remedies: A Tanzanian Perspective," Waste Manag. Integr. Vis., 2012.

[29] Republic of Rwanda, "National National E-Waste Management Policy for Rwanda," Kigali, 2016.

[30] EU Commission, "Directive 2003/108/EC of the European parliament and of the council of 8 December 2003 amending Directive 2002/96/EC on waste electrical and electronic equipment (WEEE)," Off. J. Eur. Communities, vol. L, no. 345 (31), p. 12, 2003

[31] NNW TEAM, "News From Non-Aligned World (NNW)," NNW ARTICLES, OP-EDS, 2020

[32] E. Rutebuka, L. Zhang, and M. Pang, "Simulating the dynamics of e-waste production from mobile phone: Model development and case study of Rwanda," J. Environ. Account. Manag, vol. 3, pp. 309-322, 2015.

[33] International Telecommunication Union (ITU), Measuring the information society report: 2014. 2014.

[34] T. Mito, "Rwanda E-Waste inventory," 2015.

[35] O. MBERA, "Opportunities in the Circular Economy of E-waste management Case of Rwanda," 2018. [Online]. Available:

https://www.itu.int/en/ITU-T/Workshops-and-Seminars/gs w/201804f.

[36] Africa Green Growth Forum, "Rwanda launches state-of-the-art E-Waste Recycling Facility during Green Growth Week," 2017. www.greengrowth.rw/2017/12/05.

[37] Deepali Sinha Khetriwal et al., "SUSTAINABLE MANAGEMENT OF E-WASTE IN THE OFF-GRID RENEWABLE ENERGY SECTOR IN RWANDA,” 2017.

[38] Mafaranga, "East Africa invests in strategies to manage e-waste," Eos, 101, Sep. 04, 2020.

[39] RWANDA UTILITIES REGULATORY AUTHORITY, "ESTABLISHIG A AGECY FOR THE REGULATIO OF CERTAIN PUBLIC UTILITIES,” 2001. [Online]. Available: www.rura.rw/fileadmin/laws/LawAgencyforRegul.pdf.

[40] OFFICIAL GAZETTE OF THE REPUBLIC OF RWANDA, "DETERMINING THE MODALITIES OF PROTECTION, CONSERVATION AND PROMOTION OF ENVIRONMENT IN RWANDA," 2005. [Online]. Available: $\quad$ http://vertic.org/media/National Legislation/Rwanda/RW Law 04 2005 Environment.pdf.

[41] Aime TSINDA, "Policies, Regulations and Institutional Framework for Improved Sanitation in Kigali: Rwanda Public Policy," 2011. [Online]. Available: https://core.ac.uk /download/pdf/43540645.pdf.

[42] Official Gazette n4bis, "ESTABLISHING RWANDA ENERGY, WATER AND SANITATION AUTHORITY (EWSA) AND DETERMINING ITS RESPONSIBILITIES, ORGANISATION AND FUNCTIONING,” 2011. [Online]. Available: http://extwprlegs1.fao.org/docs/pdf/rwa105461.pdf.

[43] RWANDA UTILITIES REGULATORY AUTHORITY, "Establishing Rwanda Utilities Regulatory Authority (RURA) and determining its mission, powers, organisation and functioning," 2013 
[44] JuriAfrica, "Rwanda Enacts New ICT Regulations," 2016. https://juriafrique.com/eng/2016/12/30/rwanda-enacts-newict-regulations.

[45] RWANDA UTILITIES REGULATORY AUTHORITY, "GOVERNING IMPORTATION, SUPPLY AND TYPE APPROVAL FOR ELECTRONIC COMMUNICATIONS EQUIPMENT," 2020. [Online]. Available: https://tamsys.o rg/file/b39hm3ZijytPpAc-tQ0NrRk8hUFejQCDNwMXBc CMrCK6F7.

[46] C. Shen et al., "Dioxin-like compounds in agricultural soils near e-waste recycling sites from Taizhou area, China: chemical and bioanalytical characterization," Environ. Int., vol. 35, no. 1, pp. 50-55, 2009.

[47] X. Tang et al., "Heavy metal and persistent organic compound contamination in soil from Wenling: an emerging e-waste recycling city in Taizhou area, China," J. Hazard. Mater., vol. 173, no. 1-3, pp. 653-660, 2010.

[48] R. E. Ouabo, M. B. Ogundiran, A. Y. Sangodoyin, and B. A. Babalola, "Ecological risk and human health implications of heavy metals contamination of surface soil in e-waste recycling sites in Douala, Cameroun," J. Heal. Pollut., vol. 9, no. $21,2019$.

[49] F. Nuwaha, "The challenge of chloroquine-resistant malaria in sub-Saharan Africa," Health Policy Plan., vol. 16, no. 1, pp. 1-12, 2001.

[50] Q. Guo, E. Wang, Y. Nie, and J. Shen, "Profit or environment? A system dynamic model analysis of waste electrical and electronic equipment management system in China," J. Clean. Prod., vol. 194, pp. 34-42, 2018.

[51] A. Shah, "An Assessment of Public Awareness Regarding EWaste Hazards and Management Strategies An Assessment of Public Awareness Regarding E-Waste," Indep. Study Proj. Collect., 2014.

[52] M. Noel-Brune et al., "Health effects of exposure to e-waste," Lancet Glob. Heal., vol. 1, no. 2, p. e70, 2013.

[53] P. Kiddee, R. Naidu, and M. H. Wong, "Electronic waste management approaches: An overview," Waste Manag., vol. 33, no. 5, pp. 1237-1250, 2013. 